Article

\title{
Synthetic Human $\beta$ Defensin-3-C15 Peptide in Endodontics: Potential Therapeutic Agent in Streptococcus gordonii Lipoprotein-Stimulated Human Dental Pulp-Derived Cells
}

\author{
Yeon-Jee Yoo ${ }^{1}$, Hiran Perinpanayagam ${ }^{2}{ }^{\oplus}$, Jue-Yeon Lee ${ }^{3}{ }^{\oplus}$, Soram $\mathrm{Oh}^{4}{ }^{4} \mathrm{Yu} \mathrm{Gu}^{5}$, A-Reum Kim ${ }^{6}$, \\ Seok-Woo Chang ${ }^{4}$, Seung-Ho Baek ${ }^{1}$ and Kee-Yeon Kum ${ }^{1,7, * \text { (i) }}$ \\ 1 Department of Conservative Dentistry, School of Dentistry, Dental Research Institute, Seoul National \\ University, Daehak-ro 101, Chongno-Ku, Seoul 03080, Korea; duswl32@snu.ac.kr (Y.-J.Y.); \\ shbaek@snu.ac.kr (S.-H.B.) \\ 2 Department of Dentistry, Schulich School of Medicine \& Dentistry, University of Western Ontario, London, \\ ON N6A 5C1, Canada; hperinpa@uwo.ca \\ 3 Central Research Institute, Nano intelligent Biomedical Engineering Corporation (NIBEC), Seoul 03130, \\ Korea; yeon0417@nibec.co.kr \\ 4 Department of Conservative Dentistry, School of Dentistry, Kyung Hee University, Seoul 02447, Korea; \\ soram0123@naver.com (S.O.); swc2007smc@gmail.com (S.-W.C.) \\ 5 Department of Conservative Dentistry, School of Stomatology, Shandong University, Jinan 250012, China; \\ guyu618@126.com \\ 6 Department of Oral Microbiology and Immunology, School of Dentistry, Dental Research Institute and BK21 \\ Plus Program, Seoul National University, Seoul 08826, Korea; kimareum@snu.ac.kr \\ 7 National Dental Care Center for Persons with Special Cares, Seoul National University Dental Hospital for \\ Persons with Special Needs, Seoul 03080, Korea \\ * Correspondence: kum6139@snu.ac.kr; Tel.: +(82)-2-2072-2656; Fax: +(82)-2-2072-3849
}

Received: 25 October 2019; Accepted: 17 December 2019; Published: 20 December 2019

\begin{abstract}
Human $\beta$ defensin-3-C15, an epithelium-derived cationic peptide that has antibacterial/antifungal and immuno-regulatory properties, is getting attention as potential therapeutic agent in endodontics. This study aimed to investigate if synthetic human $\beta$ defensin-3-C15 (HBD3-C15) peptides could inhibit inflammatory responses in human dental pulp cells (hDPCs), which had been induced by gram-positive endodontic pathogen. hDPC explant cultures were stimulated with Streptococcus gordonii lipoprotein extracts for $24 \mathrm{~h}$ to induce expression of pro-inflammatory mediators. The cells were then treated with either HBD3-C15 $(50 \mu \mathrm{g} / \mathrm{mL})$ or calcium hydroxide $(\mathrm{CH}, 100 \mu \mathrm{g} / \mathrm{mL})$ as control for seven days, to assess their anti-inflammatory effects. Quantitative RT-PCR analyses and multiplex assays showed that $S$. gordonii lipoprotein induced the inflammatory reaction in hDPCs. There was a significant reduction of IL-8 and MCP-1 within $24 \mathrm{~h}$ of treatment with either $\mathrm{CH}$ or HBD3-C15 ( $p<0.05)$, which was sustained over 1 week of treatment. Alleviation of inflammation in both medications was related to COX-2 expression and PGE2 secretion $(p<0.05)$, rather than TLR2 changes $(p>0.05)$. These findings demonstrate comparable effects of CH and HDB3-C15 as therapeutic agents for inflamed hDPCs.
\end{abstract}

Keywords: calcium hydroxide; chemokine; human beta defensin-3-C15; human dental pulp cell; Streptococcus gordonii lipoprotein 


\section{Introduction}

Streptococcus gordonii are Gram-positive facultative anaerobes that are frequently isolated from cases of recurrent apical periodontitis, due to their propensity to form bacterial biofilms on root canal surfaces [1]. Additionally, they can exchange genes that encode cytotoxins, adhesins, and antibiotic resistance, with Enterococcus faecalis [2]. These virulence features enable S. gordonii to play an important role in the pathogenesis of apical periodontitis.

Virulence factors in gram-positive bacteria include cell wall-associated lipoteichoic acid (LTA) and lipoproteins, which are recognized by Toll-like receptor 2 (TLR2) [3,4]. These stimulate a variety of host cells to induce pro-inflammatory cytokines and chemokines. For instance, LTA from Staphylococcus aureus or Streptococcus pyogens were shown to induce IL-8 in human peripheral blood monocytes. S. aureus lipoproteins were shown to induce IL-8 in human intestinal epithelial cells. Likewise, LTA, lipoproteins, and peptidoglycan from $S$. gordonii induced the pro-inflammatory cytokines IL- 6 and TNF $\alpha$ in dendritic cells, via TLR2 [5]. Notably, the S. gordonii lipoprotein is reported to be a key virulence factor in inducing inflammatory responses [6,7].

To inactivate virulence factors and eliminate bacteria, intracanal medicaments are often applied to root canal systems for treating apical periodontitis. The most widely used medicament is calcium hydroxide $(\mathrm{CH})$, which has antimicrobial effects that are largely due to its high $\mathrm{pH}$ [8]. It has been shown to suppress both lipopolysaccharide (LPS) [9] and LTA [10,11], which are virulence factors critical to Gram-negative and -positive bacteria respectively. More recently, antimicrobial peptides have been developed as potential therapeutic agents against microbial biofilms [12]. These include human $\beta$-defensin-3 (HBD3), which is a cysteine-rich cationic peptide that has strong antibacterial, antifungal and immuno-regulatory properties [13-16]. The disulfide topology that maintains tertiary structure in HBD3 is dispensable for its antimicrobial functions [17], and the C-terminal end of HBD3 contains 15 amino acids that effectively elicit antimicrobial activity [18]. A synthetic HBD3 peptide that consists of only 15 amino acids from the C-terminus (HBD3-C15, GKCSTRGRKCCRRKK), is being developed as an alternative antibiofilm agent (Figure 1) [12]. This 15-mer peptide derived from the C-terminus of HBD3 (HBD3-C15) has been shown to have considerable antimicrobial activity that is comparable to that of the full-length protein [18-21]. However, little is known about its suppressive effects on gram-positive bacterial virulence factors.

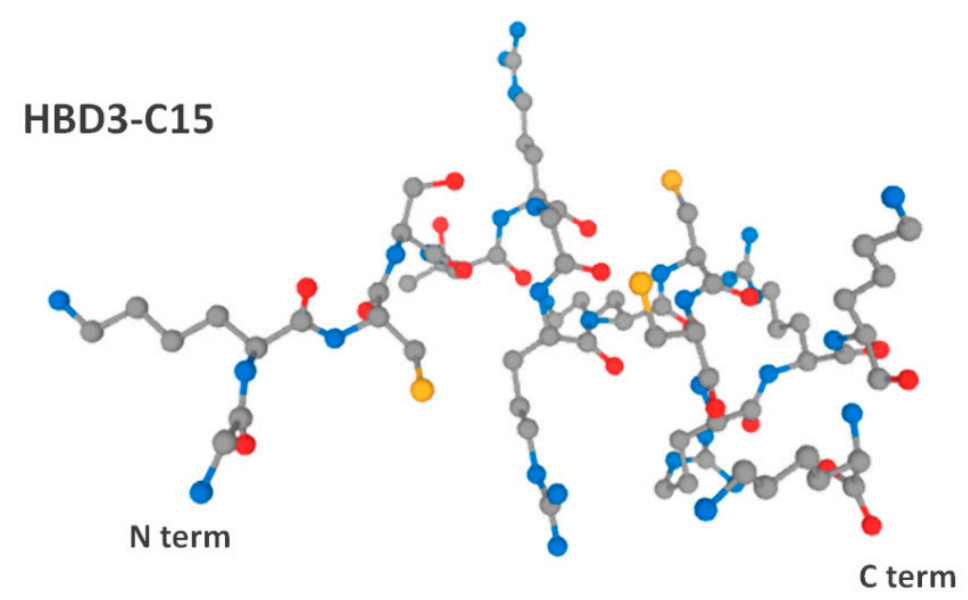

Figure 1. Molecular structure of synthetic human $\beta$ defensin-3-C15 (HBD3-C15) peptide, prepared by F-moc-based chemical solid phase synthesis from 15 amino acids (GKCSTRGRKCCRRKK). Grey, carbon; blue, nitrogen; red, oxygen; yellow, sulfur.

Where the inactivation or elimination of virulence factors are inadequate, the induction of pro-inflammatory mediators ensure a persistence of pulpitis and apical periodontitis [22,23]. Chemokines such as interleukin-8 (IL-8) and monocyte chemoattractant protein-1 (MCP-1) display potent chemotactic activities for human neutrophils and $\mathrm{T}$ lymphocytes, which in turn trigger 
a series of inflammatory events [24] that release enzymes causing tissue destruction [25]. Accompanying inflammatory mediators such as cyclooxygenase 2 (COX-2) stimulate vasodilation and microvascular permeability by cytoskeletal rearrangement or contraction of vascular smooth muscle [26]. Therefore, the purpose of this study was to examine the anti-inflammatory properties of HBD3-C15 in human dental pulp cells (hDPCs) that had been stimulated by S. gordonii derived lipoprotein, by comparing the effects of HBD3-C15 and $\mathrm{CH}$.

\section{Results}

\subsection{S. gordoni Lipoproteins Induced Inflammatory Mediators}

S. gordonii lipoprotein induced the expression of chemokines IL-8 and MCP-1 by hDPC explant cultures (Figure 2). When hDPCs were treated with Triton X-114 extracts from S. gordonii that contained the bacterial lipoproteins [27], there was an immediate increase in the relative mRNA expressions of IL- 8 and MCP-1, as measured by real-time RT-qPCR. The relative levels of IL- 8 and MCP-1 were significantly higher $(p<0.05)$ in the S. gordonii lipoprotein-treated hDPCs, than in the untreated cultures.

a

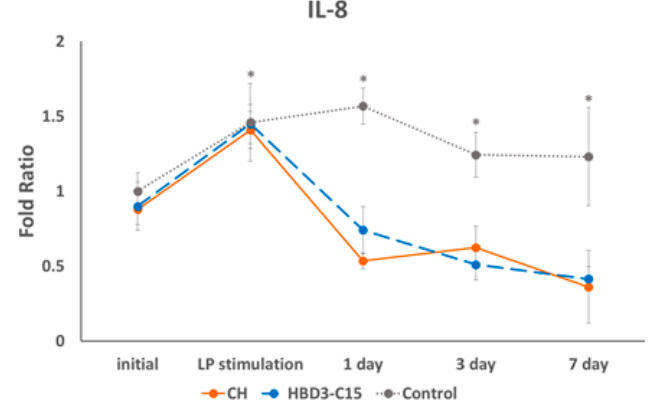

b

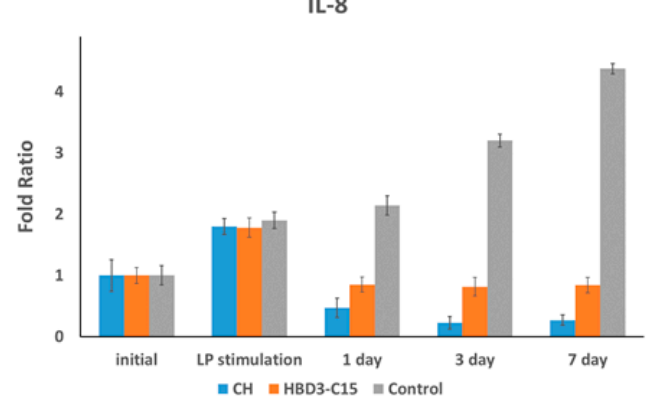

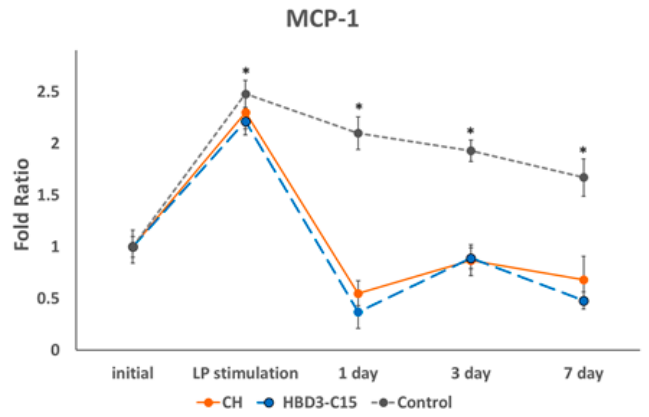

MCP-1

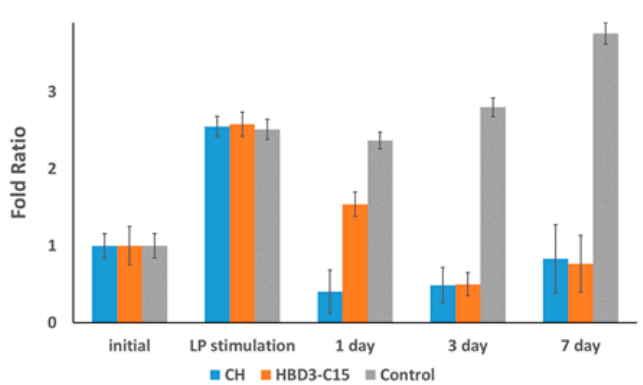

Figure 2. Cultured human dental pulp cells (hDPCs) experienced an inflammatory reaction after Gram-positive S. gordonii lipoprotein (LP)-stimulation, and then inflamed hDPCs were treated with either calcium hydroxide (CH) or HBD3-C15. Cell lysates were collected at the indicated time points, and the expressions of IL-8 and MCP-1 were analyzed by (a) qRT-PCR and (b) multiplex assay. The relative expression levels of each control group are presented.

\subsection{HBD3-C15 and CH Suppress Inflammatory Mediators}

The stimulated cells were then treated with either HBD3-C15 or $\mathrm{CH}$. The medicaments were not simultaneously treated with $S$. gordonii lipoprotein, to prevent the interactions and denaturation of S. gordonii lipoprotein with positively charged HBD3-C15 or highly alkaline $\mathrm{CH}$, and also to reenact clinical relevance in endodontics. Both HBD3-C15 and $\mathrm{CH}$ treatments for 1,3, and 7 days, suppressed the expression of IL-8 and MCP-1 mRNA measured by qRT-PCR (Figure 2a), and their protein level quantified by multiplex assay (Figure $2 b$ ). There were significant and sustained reductions in IL- 8 and MCP-1 mRNA gene expression and their quantified protein level, to the levels those were at or below their baselines values $(p<0.05)$. There were no significant differences between these two medicaments 
$(p>0.05)$. Non-medicated cells showed sustained inflammatory status, with increased protein level over time.

\subsection{Anti-Inflammatory Effects of HBD3-C15 and CH Were not Mediated by TLR2}

To investigate the underlying anti-inflammatory mechanism of HBD3-C15 and CH, TLR2 mRNA expression level was assessed in hDPCs. S. gordonii lipoproteins induced upregulated TLR2 expression in hDPCs $(p<0.05)$. However, TLR2 gene expression level were not decreased after medication (Figure 3a). To validate the result, we examined HEK292-TLR2 cell transfection and found that S. gordonii lipoproteins potently stimulated NF-KB in HEK292-TLR2 cells as in hDPCs, but there were no significant differences after medication (Figure $3 b, p>0.05$ ).

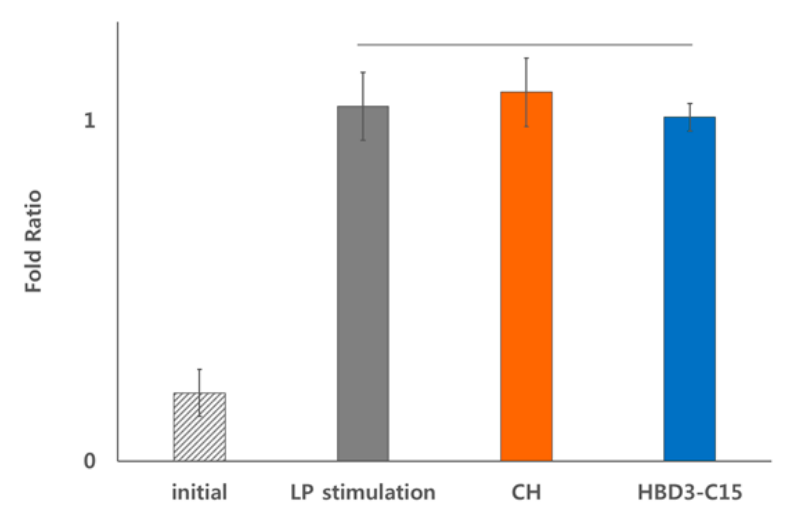

(a)

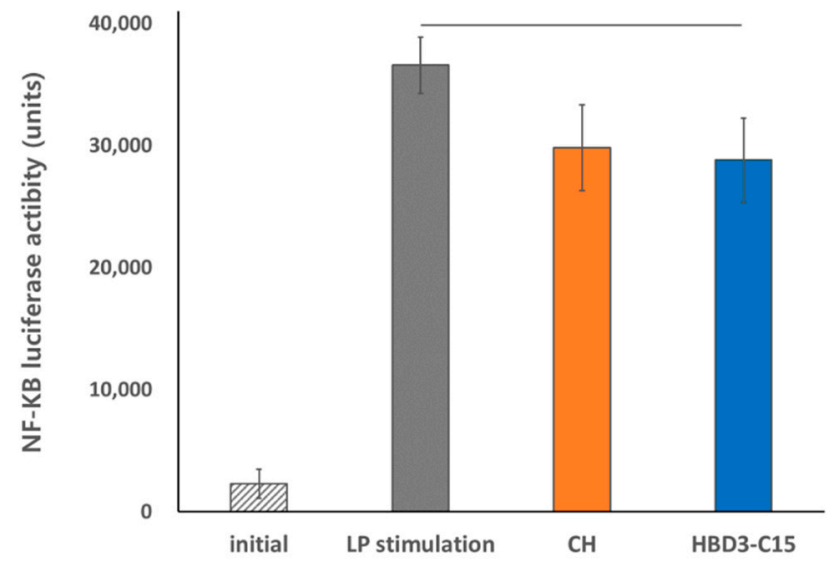

(b)

Figure 3. (a) Exogenous stimulation of $S$. gordonii lipoproteins augment TLR2 mRNA expressions in hDPCs, and were maintained after calcium hydroxide $(\mathrm{CH})$ or HBD3-C15 treatment. (b) S. gordonii lipoprotein-stimulated NF-KB are mediated by TLR2. HEK-TLR2 cells $\left(2.5 \times 10^{5}\right.$ cells/mL $)$ were transfected with an NF-kB luciferase reporter plasmid using Attractene transfection reagent. After $16 \mathrm{~h}$, the cells were stimulated with lipoprotein purified from $S$. gordonii, and then treated with either of $\mathrm{CH}$ or HBD3-C15. After the cells were lysed, a luciferease assay was conducted.

\subsection{Anti-Inflammatory Effects Were Related to COX-2 Expression and PGE2 Level}

To extend the findings to speculate on the mechanism of inflammatory status changes after treatment, we investigated the inflammatory marker COX-2 changes of inflamed hDPCs, which is known to be upregulated in pulpal inflammations [28]. It was found that the COX-2 gene expression and PGE2 level were significantly upregulated after S. gordonii stimulation of hDPCs $(p<0.05)$, and were significantly alleviated after $24 \mathrm{~h}$ of $\mathrm{CH}$ and HBD3-C15 treatments $(p<0.05)$, and maintained at low level (Figure 4). There was no significant differences between the two medicaments $(p>0.05)$. 
a

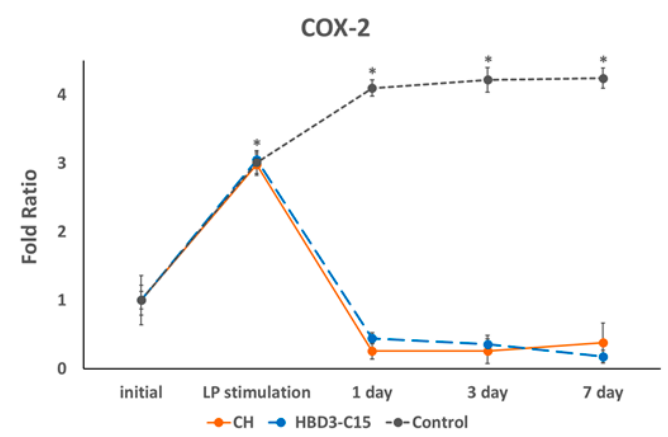

b

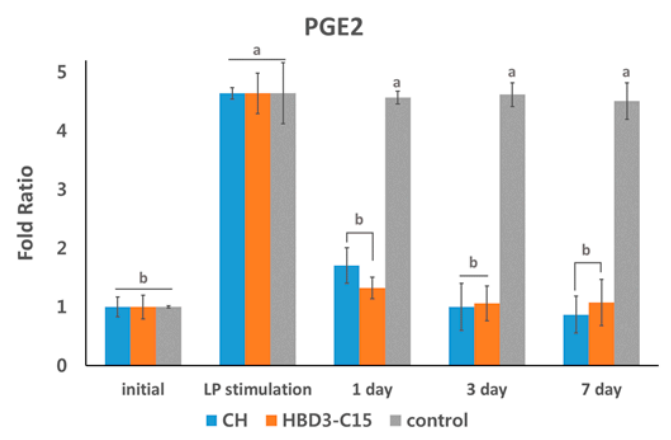

Figure 4. (a) Expression of COX-2 gene in S. gordonii lipoprotein-stimulated hDPCs after treatment with calcium hydroxide (CH) or HBD3-C15 at determined time points and (b) PGE2 secretion levels accordingly. The relative expression levels to each control group are presented.

\section{Discussion}

Pulp and periapical inflammation are initiated and propagated by chemokines. The pro-inflammatory chemokines IL- 8 and MCP- 1 are associated with the recruitment of cells to sites of inflammation. A predominant cellular source of IL-8 and MCP-1 are mononuclear phagocytes. However, IL-8 and MCP-1 can also be produced by nonimmune cells, such as fibroblasts, keratinocytes, and endothelial cells in response to either endogenous or exogenous stimuli. The cytokines produced by mononuclear cells are important mediators for chemokine production by cells such as dental pulp fibroblasts, which respond to invading microorganisms and produce chemokines. In dental pulp, the elevation of MCP-1 that is a chemo-attractant, gathers immune cells (to resist infection), which release more pro-inflammatory mediators and inflammatory cells within the tissues $[29,30]$.

Recently, some lipoproteins from gram-positive bacteria were found to be triacylated, which are native ligands of TLR2 [31]. TLR2, along with other pattern recognition receptors (PRRs), are functionally the predominant receptors that stimulate production of the inflammatory mediators, IL-8, IL-6, MCP-1, and PGE2. Therefore, these receptors play important roles in the immune response of the dental pulp, and the progression of pulpitis [32]. Their expression in hDPCs alone appears to upregulate pro-inflammatory mediators. Likewise, our prior study reported that $S$. gordonii induces nitric oxide production through the TLR2 signaling pathway, and lipoprotein is responsible for the induction [7].

Now, this study has shown that the upregulated expression of inflammatory mediators in hDPCs that have been stimulated with $S$. gordonii lipoprotein can be attenuated by either CH or HBD3-C15. Such a capacity to reduce pulpal inflammation, especially in regenerative endodontic procedures on immature teeth may be particularly beneficial. The anti-inflammatory effects of $\mathrm{CH}$ are less understood than its known antimicrobial activity. $\mathrm{CH}$ inactivates the LPS of gram-negative bacteria, by hydrolyzing fatty acids in the lipid A moiety [9,33-35]. Additionally, it inactivates the LTA of gram-positive bacteria by deacylation, which inhibits their binding of TLR2 [10,11]. However in this study CH and HBD3-C15 suppressed lipoprotein-induced inflammation without blocking TLR2 signaling. It is speculated that the inflammation control of $\mathrm{CH}$ and $\mathrm{HBD} 3-\mathrm{C} 15$ as an endodontic medicament did not affect immune related signals in bacterial virulence factor-induced inflammation.

In this study, definite alleviation of the upregulated COX-2 as well as increased PGE2 secretion were observed in after $\mathrm{CH}$ - or HBD3-C15-treated hDPCs. Considering that PGE2 could enhance pain transmission in neuro-inflammation [36], the medication-dictated modulation of PGE2 release may provide a plausible background for why $\mathrm{CH}$ has been advocated for wide use in endodontics, and also adduce the possibility of HBD3-C15 as an alternative medicament. COX-2 is a membrane associated enzyme that produces PGE2 at sites of pulpal injury and inflammation, which leads to tissue swelling, redness, and pain [37]. As COX-2 participates in the regulation of prostanoid formation in the pathogenesis of pulpal inflammation, it was suggested that COX-2 may play a pivotal role in generating high levels of PGE2 locally resulting in pulpal tissue destruction, which formed the 
first investigation into using COX-2 inhibitors to control pulpal inflammation [38]. It is necessary to further investigate the effects of $\mathrm{CH}$ and $\mathrm{HBD} 3-\mathrm{C} 15$ on differential signal transduction pathways that mediate COX-2 stimulation and PGE2 production in hDPCs, instead of direct effect on TLR2 pathway. Another important clinical factor of the two chemicals would be a topical action in the control of inflammation, which could reduce the side effects of systemic anti-inflammatory drugs (i.e., NSAIDs). However, further studies are necessary to decipher the details of this mechanism.

The anti-inflammatory effects of HBD3-C15 peptide that were found in TLR-2 mediated inflammation in this study, were not in accordance with prior reports on the full length HBD3 protein pathways $[16,39,40]$. Just as other AMPs that permeabilize microbial membranes and neutralize or disaggregate LPS [16], full length HBD3 can bind directly to LPS and prevent the binding of LPS to host cell receptors $[16,39,40]$ through TLR-4 mediated signaling pathways and the subsequent transcriptional inhibition of inflammatory genes [41]. It has also been suggested that full length HBD3 has anti-inflammatory properties that do not involve direct peptide binding to LPS, in macrophages isolated from human bone marrow [40]. However, this therapeutic application of full length HBD3 is limited by its molecular size, the complexity of disulfide pairing, and attenuated activity at elevated ionic strength. To overcome these limitations and identify the active peptide fragments within HBD3, the C-terminal HBD3 peptide was modified by substituting serine for cysteine residues, and shown to have retained its anti-microbial activity [42]. Recent reports showed that HBD3-C15 peptide could attenuate LPS-induced bone resorption, by disrupting podosome belt formation in osteoclasts and suppressing their differentiation [43]. In anti-inflammatory effect, HBD3-C15 did not affect upregulated TLR-2 level and its following signaling pathways in this study. This may have been due to the study design where $\mathrm{CH}$ paste and HBD3-C15 treatments were not applied simultaneously with S. gordonii lipoprotein. This was important to avoid the possible impairment or denaturation of lipoprotein and subsequent inflammatory mediators by $\mathrm{CH}$ or HBD3-C15, and to focus solely on the changes in lipoprotein-stimulated hDPCs.

Collectively, the results of this study support the use of $\mathrm{CH}$ and HBD3-C15 as intracanal medicaments, which may be particularly important for regenerative endodontic procedures in immature necrotic teeth. The synthetic HBD3-C15 peptide has multiple properties that are beneficial for its therapeutic application as an intracanal medicament in recurrent apical periodontitis and also in regenerative endodontic procedures for immature necrotic teeth.

\section{Materials and Methods}

\subsection{Human Dental Pulp Cell Explant Cultures}

Human dental pulp cell (hDPCs) explants were grown from the pulps of extracted teeth, which had been approved for collection by the Institutional Review Board of Seoul National University (S-D2014007, 27 March 2014). Crowns of freshly extracted teeth were split open and their pulps carefully harvested. The pulp tissues were diced into fine fragments in culture dishes (Nalge Nunc International, Rochester, NY, USA), and incubated in DMEM (Dulbecco's modified Eagle's medium) supplemented with 10\% fetal bovine serum (FBS) and 1\% penicillin-streptomycin, with fresh media replenished every 3 days. After 3 weeks of growth, the cells that had extended out from the tissue fragments were carefully harvested and sub-cultured. Following 4-6 passages, cells were utilized in experiments such that each independent experiment was performed with cells from the same passages.

The viability of hDPCs was quantitatively assessed in the presence of $\mathrm{CH}$ and HBD3-C15 using a cell counting kit (CellCountEZ ${ }^{\mathrm{TM}}$ Cell Survival assay kit, Rockland Immunochemicals, Posttown, PA, USA). Briefly, the hDPCs were seeded in a 96-well plate at a density of $2 \times 10^{3}$ cells/well and cultured with different concentrations of reagents for $24 \mathrm{~h}$. The absorbance was measured with a microplate reader (Bio-Rad Laboratories, Hercules, CA, USA) at $490 \mathrm{~nm}$ (Figure 5). 
$\mathrm{CH}$

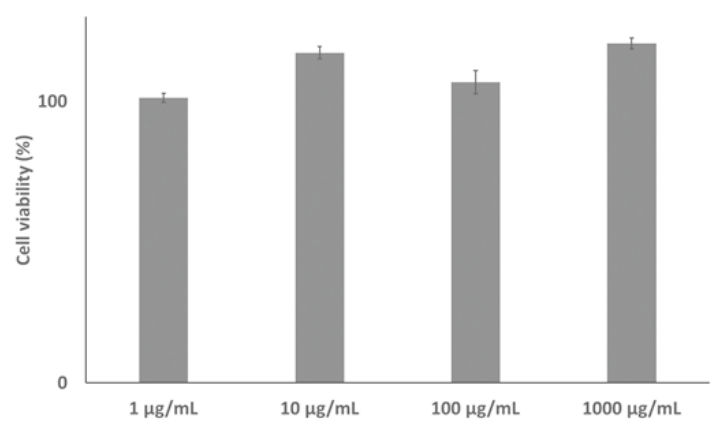

HBD3-C15

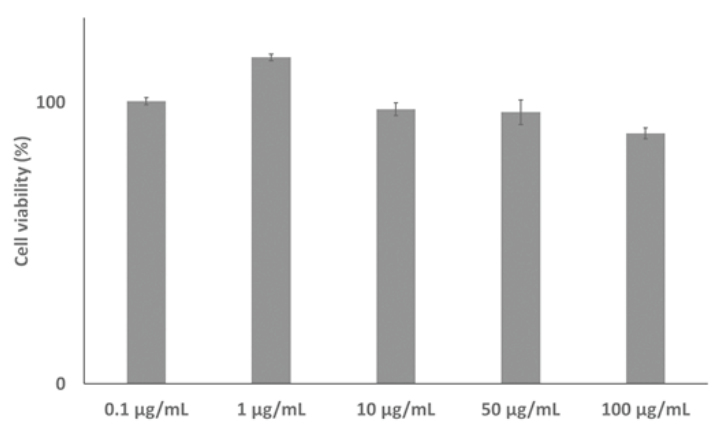

Figure 5. The survival rate of hDPCs was assessed in the presence of calcium hydroxide $(\mathrm{CH})$ and HBD3-C15 using a cell counting kit (CellCountEZ ${ }^{\mathrm{TM}}$ Cell Survival assay kit, Rockland Immunochemicals, Posttown, PA, USA). Briefly, the hDPCs were seeded in a 96-well plate at a density of $2 \times 10^{3}$ cells/well and cultured with different concentrations of reagents for $24 \mathrm{~h}$. The absorbance was measured with a microplate reader (Bio-Rad Laboratories, Hercules, CA, USA) at $490 \mathrm{~nm}$.

\subsection{S. gordonii Lipoprotein Extracts}

Bacterial lipoproteins were isolated and purified from S. gordonii, as previously reported [44]. Briefly, bacterial pellets were collected and suspended in Tris-buffered saline (TBS) with protease inhibitors. They were sonicated, the lysates suspended in a final concentration of $2 \%$ Triton X-114 at $4{ }^{\circ} \mathrm{C}$ for $2.5 \mathrm{~h}$, and then centrifuged to discard cell debris. The supernatant was incubated at $37^{\circ} \mathrm{C}$ for $15 \mathrm{~min}$ and centrifuged again to separate the Triton X-114 phase from the aqueous phase which was discarded. An equal volume of TBS was added to the Triton X-114 phase, incubated at $37^{\circ} \mathrm{C}$ for $15 \mathrm{~min}$, and centrifuged again to discard the aqueous phase. Finally, the Triton X-114 phase was incubated overnight with methanol at $-20^{\circ} \mathrm{C}$, and lipoprotein precipitates collected and dissolved in $10 \mathrm{mM}$ octyl-beta-D-glucopyranoside in PBS.

\subsection{Cell Transfection}

HEK293-TLR2 cells were transfected as previously described [45]. Briefly, HEK293-TLR2 cells $\left(2.5 \times 10^{5}\right.$ cells $/ \mathrm{mL}, 5 \mathrm{~mL}, 60 \mathrm{~mm}$ dishes) were transfected with an NF- $\mathrm{KB}$ (nuclear factor- $\mathrm{kB}$ ) reporter gene construct (pNF-kB-Luc, Clontech, Mountain View, CA, USA). Transfections were performed in Opti-MEM using Attractene transfection reagent for $16 \mathrm{~h}$ (Qiagen, Germantown, MD, USA). After collection, the cells $\left(2.5 \times 10^{5}\right.$ cells $/ \mathrm{mL}, 200 \mu \mathrm{L}$, 96-well plates) were plated in complete DMEM. The cells were then stimulated with S. gordonii lipoprotein and lysed with GloLysis Buffer (Promega, Madison, WI, USA). The cytoplasmic extracts were assayed with a luminometer (Molecular Devices, Sunnyvale, CA, USA) for luciferase activity.

\subsection{Peptide Preparation}

Peptides were synthesized at the central research institute of NIBEC using a peptide synthesizer (Prelude, Protein Technologies Inc., Tucson, AZ, USA) to produce the C-terminal amide form using standard 9-fluorenylmethoxycarbonyl (F-moc) chemistry and purified using preparative reverse-phase high-performance liquid chromatography (RP-HPLC; Waters, Milford, MA, USA) with a Vydac C18 column and a 50-min gradient from $90 \%$ to $10 \%$ water/acetonitrile containing $0.1 \%$ trifluoroacetic acid (TFA). The purity of the peptides was determined using HPLC (Shimadzu, Kyoto, Japan) and liquid chromatography-mass spectrometry (LC-MS, Shimadzu, Kyoto, Japan). The purity of the peptide was measured as $99.3 \%$ and the molecular weight of the peptide was identified as 1766.17 (Da) using LC-MS.

\subsection{Inflammatory Chemokine Analysis}

The hDPCs $\left(2.5 \times 10^{5}\right.$ cells $\left./ \mathrm{mL}\right)$ were plated in six well plates and stimulated with $10 \mu \mathrm{g} / \mathrm{mL}$ of lipoprotein extracts for $24 \mathrm{hrs}$. The stimulated cells were then treated with either $\mathrm{CH}$ (DC Chemical 
Co Ltd., Seoul, Korea) mixed with distilled water $(100 \mu \mathrm{g} / \mathrm{mL})$ as the control, or synthetic HBD3-C15 peptide gel $(50 \mu \mathrm{g} / \mathrm{mL})$. The synthetic HBD3-C15 peptide (NIBEC, Seoul, Korea) was prepared by F-moc-based chemical solid phase synthesis from 15 amino acids (GKCSTRGRKCCRRKK). It was used at a concentration $(50 \mu \mathrm{g} / \mathrm{mL})$ that was found to be effective in a previous study [14].

Time points were chosen that included before and after $24 \mathrm{~h}$ of lipoprotein stimulation, as well as after 1,3, and 7 days of the treatments with either $\mathrm{CH}$ or HBD3-C15. At these predetermined times, replicate $(\mathrm{N}=3)$ hDPC cultures were harvested and their total cell RNA extracted with RNAiso Plus reagents (Takara, Otsu, Japan). The cDNA was synthesized with gene-specific reverse primers for humans (Table 1) by using the PrimeScript RT reagent kit (Takara). Reverse transcription-quantitative polymerase chain reaction (RT-qPCR) was done with a C1000 Real-time PCR system thermal cycler (Bio-Rad, Hercules, CA, USA). The level of the target gene transcripts $(\triangle \mathrm{CT}$ ) was normalized to that of glyceraldehyde-3-phosphate dehydrogenase (Gapdh). The relative levels of expression in the experimental group were calculated by $\Delta(\Delta \mathrm{CT})\left(\Delta \mathrm{CT}_{\mathrm{Control}}-\Delta \mathrm{CT}_{\text {Experiment }}\right)$. The findings were verified by multiplex analysis according to the manufacturers' instructions. Data was collected using the Luminex-100 system (ver. 1.7, Luminex, Austin, TX, USA) and analyzed by using the Milliplex Analyst (Viagene Tech, Carlisle, MA, USA). A five-parameter regression formula was used to calculate the concentrations from the standard curves. Reported data as normalized pg/mL was assessed. All reactions were run in triplicate.

Table 1. Sequences of primers used in RT-qPCR.

\begin{tabular}{ccc}
\hline Gene (Human) & Primer $\left(5^{\prime} \rightarrow 3^{\prime}\right)$ \\
\hline \multirow{2}{*}{$I L-8$} & $\begin{array}{c}\text { Forward } \\
\text { Reverse }\end{array}$ & $\begin{array}{c}\text { AGGGTTGCCAGATGCAATAC } \\
\text { CCTTGGCCTCAATTTGCTA }\end{array}$ \\
\hline \multirow{2}{*}{$M C P-1$} & $\begin{array}{c}\text { Forward } \\
\text { Reverse }\end{array}$ & $\begin{array}{c}\text { GCAGCAAGTGTCCCAAAGA } \\
\text { ACAGGGTGTCTGGGGAAAG }\end{array}$ \\
\hline \multirow{2}{*}{ COX2 } & $\begin{array}{c}\text { Forward } \\
\text { Reverse }\end{array}$ & TTCAAATGAGATTGTGGGAAAATTGCT \\
& FGATCATCTCTGCCTGAGTATCTT \\
\hline \multirow{2}{*}{ F 2} & Reverse & CCCATTGCTCTTTCACTGCT \\
\multirow{2}{*}{ GAPDH } & Forward & CTTCCTTGGAGAGGCTGATG \\
& Reverse & GGCTGAGAACGGGAAGCTT \\
\hline
\end{tabular}

\subsection{Statistical Analysis}

Replicate cultures were compared both before and after lipoprotein-stimulation, and then after treatment with either calcium hydroxide or HBD3-C15 for 1, 3, and 7 days. Data were analyzed statistically by a one-way analysis of variance (ANOVA) and Tukey's post-hoc test to a significance of $P<0.05$.

Author Contributions: Conceptualization: K.-Y.K.; data curation: Y.-J.Y., J.-Y.L., A.-R.K., K.-Y.K.; formal analysis: J.-Y.L., S.O., A.-R.K., Y.G.; investigation: H.P., K.-Y.K.; methodology: J.-Y.L., K.-Y.K.; resources: S.-H.B., S.-W.C., K.-Y.K.; funding: S.-H.B., K.-Y.K.; supervision: K.-Y.K.; validation: H.P.; writing-original draft preparation: Y.-J.Y., K.-Y.K.; writing - review and editing: H.P., K.-Y.K. All authors read and approved the final manuscript. All authors have read and agreed to the published version of the manuscript.

Funding: This study was supported by Seoul National University Dental Hospital Research Fund [04-2018-0102, 02-2019-0008], and the Korea Health Technology R\&D Project through the Korea Health Industry Development Institute (KHIDI) and the Ministry of Health \& Welfare (HI17C1377).

Conflicts of Interest: All authors declare that they have no conflicts of interest.

Ethical Approval: Study approval was obtained from the Institutional Review Board of Seoul National University Dental Hospital (IRB125/05-16). 


\section{References}

1. Love, R.M.; Jenkinson, H.F. Invasion of dentinal tubules by oral bacteria. Crit. Rev. Oral. Biol. Med. 2002, 13, 171-183. [CrossRef] [PubMed]

2. Sedgley, C.M.; Lee, E.H.; Martin, M.J.; Flannagan, S.E. Antibiotic resistance gene transfer between Streptococcus gordonii and Enterococcus faecalis in root canals of teeth ex vivo. J. Endod. 2008, 34, 570-574. [CrossRef] [PubMed]

3. Brightbill, H.D.; Libraty, D.H.; Krutzik, S.R.; Yang, R.B.; Belisle, J.T.; Bleharski, J.R.; Maitland, M.; Norgard, M.V.; Plevy, S.E.; Smale, S.T.; et al. Host defense mechanisms triggered by microbial lipoproteins through toll-like receptors. Science 1999, 285, 732-736. [CrossRef] [PubMed]

4. Nguyen, M.T.; Gotz, F. Lipoproteins of Gram-Positive Bacteria: Key Players in the Immune Response and Virulence. Microbiol. Mol. Biol. Rev. 2016, 80, 891-903. [CrossRef] [PubMed]

5. Mayer, M.L.; Phillips, C.M.; Townsend, R.A.; Halperin, S.A.; Lee, S.F. Differential activation of dendritic cells by toll-like receptor agonists isolated from the gram-positive vaccine vector Streptococcus gordonii. Scand. J. Immunol. 2009, 69, 351-356. [CrossRef]

6. Kim, A.R.; Ahn, K.B.; Kim, H.Y.; Seo, H.S.; Kum, K.Y.; Yun, C.H.; Han, S.H. Streptococcus gordonii lipoproteins induce IL-8 in human periodontal ligament cells. Mol. Immunol. 2017, 91, 218-224. [CrossRef]

7. Kim, H.Y.; Baik, J.E.; Ahn, K.B.; Seo, H.S.; Yun, C.H.; Han, S.H. Streptococcus gordonii induces nitric oxide production through its lipoproteins stimulating Toll-like receptor 2 in murine macrophages. Mol. Immunol. 2017, 82, 75-83. [CrossRef]

8. Siqueira, J.F., Jr.; Lopes, H.P. Mechanisms of antimicrobial activity of calcium hydroxide: A critical review. Int. Endod. J. 1999, 32, 361-369. [CrossRef]

9. Safavi, K.E.; Nichols, F.C. Effect of calcium hydroxide on bacterial lipopolysaccharide. J. Endod. 1993, 19, 76-78. [CrossRef]

10. Baik, J.E.; Jang, K.S.; Kang, S.S.; Yun, C.H.; Lee, K.; Kim, B.G.; Kum, K.Y.; Han, S.H. Calcium hydroxide inactivates lipoteichoic acid from Enterococcus faecalis through deacylation of the lipid moiety. J. Endod. 2011, 37, 191-196. [CrossRef]

11. Baik, J.E.; Kum, K.Y.; Yun, C.H.; Lee, J.K.; Lee, K.; Kim, K.K.; Han, S.H. Calcium hydroxide inactivates lipoteichoic acid from Enterococcus faecalis. J. Endod. 2008, 34, 1355-1359. [CrossRef] [PubMed]

12. Wang, Z.; Shen, Y.; Haapasalo, M. Antibiofilm peptides against oral biofilms. J. Oral Microbiol. 2017, 9, 1327308. [CrossRef] [PubMed]

13. Schneider, J.J.; Unholzer, A.; Schaller, M.; Schafer-Korting, M.; Korting, H.C. Human defensins. J. Mol. Med. 2005, 83, 587-595. [CrossRef] [PubMed]

14. Lee, J.K.; Chang, S.W.; Perinpanayagam, H.; Lim, S.M.; Park, Y.J.; Han, S.H.; Baek, S.H.; Zhu, Q.; Bae, K.S.; Kum, K.Y. Antibacterial efficacy of a human beta-defensin-3 peptide on multispecies biofilms. J. Endod. 2013, 39, 1625-1629. [CrossRef]

15. Lee, J.K.; Park, Y.J.; Kum, K.Y.; Han, S.H.; Chang, S.W.; Kaufman, B.; Jiang, J.; Zhu, Q.; Safavi, K.; Spangberg, L. Antimicrobial efficacy of a human beta-defensin-3 peptide using an Enterococcus faecalis dentine infection model. Int. Endod. J. 2013, 46, 406-412. [CrossRef]

16. Zhang, L.J.; Gallo, R.L. Antimicrobial peptides. Curr. Biol. 2016, 26, R14-R19. [CrossRef]

17. Wu, Z.; Hoover, D.M.; Yang, D.; Boulegue, C.; Santamaria, F.; Oppenheim, J.J.; Lubkowski, J.; Lu, W. Engineering disulfide bridges to dissect antimicrobial and chemotactic activities of human beta-defensin 3. Proc. Natl. Acad. Sci. USA 2003, 100, 8880-8885. [CrossRef]

18. Hoover, D.M.; Wu, Z.; Tucker, K.; Lu, W.; Lubkowski, J. Antimicrobial characterization of human beta-defensin 3 derivatives. Antimicrob. Agents Chemother. 2003, 47, 2804-2809. [CrossRef]

19. Krishnakumari, V.; Rangaraj, N.; Nagaraj, R. Antifungal activities of human beta-defensins HBD-1 to HBD-3 and their C-terminal analogs Phd1 to Phd3. Antimicrob. Agents Chemother. 2009, 53, 256-260. [CrossRef]

20. Casalinuovo, I.A.; Sorge, R.; Bonelli, G.; Di Francesco, P. Evaluation of the antifungal effect of EDTA, a metal chelator agent, on Candida albicans biofilm. Eur. Rev. Med. Pharmacol. Sci. 2017, 21, 1413-1420.

21. Lim, S.M.; Ahn, K.B.; Kim, C.; Kum, J.W.; Perinpanayagam, H.; Gu, Y.; Yoo, Y.J.; Chang, S.W.; Han, S.H.; Shon, W.J.; et al. Antifungal effects of synthetic human beta-defensin 3-C15 peptide. Restor. Dent. Endod. 2016, 41, 91-97. [CrossRef] [PubMed] 
22. Tsai, C.H.; Chen, Y.J.; Huang, F.M.; Su, Y.F.; Chang, Y.C. The upregulation of matrix metalloproteinase-9 in inflamed human dental pulps. J. Endod. 2005, 31, 860-862. [CrossRef] [PubMed]

23. Huang, G.T.; Potente, A.P.; Kim, J.W.; Chugal, N.; Zhang, X. Increased interleukin-8 expression in inflamed human dental pulps. Oral Surg. Oral Med. Oral Pathol. Oral Radiol. Endod. 1999, 88, 214-220. [CrossRef]

24. Rechenberg, D.K.; Galicia, J.C.; Peters, O.A. Biological Markers for Pulpal Inflammation: A Systematic Review. PLoS ONE 2016, 11, e0167289. [CrossRef] [PubMed]

25. Lacy, P. Mechanisms of degranulation in neutrophils. Allergy Asthma Clin. Immunol. 2006, 2, 98-108. [CrossRef] [PubMed]

26. Omori, K.; Kida, T.; Hori, M.; Ozaki, H.; Murata, T. Multiple roles of the PGE2 -EP receptor signal in vascular permeability. Br. J. Pharmacol. 2014, 171, 4879-4889. [CrossRef]

27. Bordier, C. Phase separation of integral membrane proteins in Triton X-114 solution. J. Biol. Chem. 1981, 256, $1604-1607$.

28. Chen, C.L.; Kao, C.T.; Ding, S.J.; Shie, M.Y.; Huang, T.H. Expression of the inflammatory marker cyclooxygenase- 2 in dental pulp cells cultured with mineral trioxide aggregate or calcium silicate cements. J. Endod. 2010, 36, 465-468. [CrossRef]

29. Park, J.; Choi, K.; Jeong, E.; Kwon, D.; Benveniste, E.N.; Choi, C. Reactive oxygen species mediate chloroquine-induced expression of chemokines by human astroglial cells. Glia 2004, 47, 9-20. [CrossRef]

30. Park, S.H.; Hsiao, G.Y.; Huang, G.T. Role of substance $P$ and calcitonin gene-related peptide in the regulation of interleukin-8 and monocyte chemotactic protein-1 expression in human dental pulp. Int. Endod. J. 2004, 37, 185-192. [CrossRef]

31. Kurokawa, K.; Lee, H.; Roh, K.B.; Asanuma, M.; Kim, Y.S.; Nakayama, H.; Shiratsuchi, A.; Choi, Y.; Takeuchi, O.; Kang, H.J.; et al. The triacylated ATP binding cluster transporter substrate-binding lipoprotein of Staphylococcus aureus functions as a native ligand for toll-like receptor 2. J. Biol. Chem. 2009, 284, 8406-8411. [CrossRef] [PubMed]

32. Hirao, K.; Yumoto, H.; Takahashi, K.; Mukai, K.; Nakanishi, T.; Matsuo, T. Roles of TLR2, TLR4, NOD2, and NOD1 in pulp fibroblasts. J. Dent. Res. 2009, 88, 762-767. [CrossRef] [PubMed]

33. Barthel, C.R.; Levin, L.G.; Reisner, H.M.; Trope, M. TNF-alpha release in monocytes after exposure to calcium hydroxide treated Escherichia coli LPS. Int. Endod. J. 1997, 30, 155-159. [CrossRef] [PubMed]

34. Buck, R.A.; Cai, J.; Eleazer, P.D.; Staat, R.H.; Hurst, H.E. Detoxification of endotoxin by endodontic irrigants and calcium hydroxide. J. Endod. 2001, 27, 325-327. [CrossRef]

35. Jiang, J.; Zuo, J.; Chen, S.H.; Holliday, L.S. Calcium hydroxide reduces lipopolysaccharide-stimulated osteoclast formation. Oral Surg. Oral Med. Oral Pathol. Oral Radiol. Endod. 2003, 95, 348-354. [CrossRef]

36. Jiang, J.; Yu, Y.; Kinjo, E.R.; Du, Y.; Nguyen, H.P.; Dingledine, R. Suppressing pro-inflammatory prostaglandin signaling attenuates excitotoxicity-associated neuronal inflammation and injury. Neuropharmacology 2019, 149, 149-160. [CrossRef]

37. Nakanishi, T.; Shimizu, H.; Hosokawa, Y.; Matsuo, T. An immunohistological study on cyclooxygenase-2 in human dental pulp. J. Endod. 2001, 27, 385-388. [CrossRef]

38. Chang, Y.C.; Yang, S.F.; Huang, F.M.; Liu, C.M.; Tai, K.W.; Hsieh, Y.S. Proinflammatory cytokines induce cyclooxygenase-2 mRNA and protein expression in human pulp cell cultures. J. Endod. 2003, 29, 201-204. [CrossRef]

39. Chung, P.Y.; Khanum, R. Antimicrobial peptides as potential anti-biofilm agents against multi-drug resistant bacteria. J. Microbiol. Immunol. 2017, 50, 405-410. [CrossRef]

40. Semple, F.; Webb, S.; Li, H.N.; Patel, H.B.; Perretti, M.; Jackson, I.J.; Gray, M.; Davidson, D.J.; Dorin, J.R. Human beta-defensin 3 has immunosuppressive activity in vitro and in vivo. Eur. J. Immunol. 2010, 40, 1073-1078. [CrossRef]

41. Semple, F.; MacPhereson, H.; Webb, S.; Cox, S.L.; Mallin, J.L.; Tyrrell, C.; Grimes, G.R.; Semple, C.A.; Nix, M.A.; Millhouser, G.L.; et al. Human $\beta$-defensin 3 affects the activity of pro-inflammatory pathways associated with MyD88 and TRIF. Eur. J. Immunol. 2011, 41, 3291-3330. [CrossRef] [PubMed]

42. Lee, J.Y.; Suh, J.S.; Kim, J.M.; Kim, J.H.; Park, H.J.; Park, Y.J.; Chung, C.P. Identification of a cell-penetrating peptide domain from human beta-defensin 3 and characterization of its anti-inflammatory activity. Int. J. Nanomed. 2015, 10, 5423-5434. [CrossRef]

43. Park, O.J.; Kim, J.; Ahn, K.B.; Lee, J.Y.; Park, Y.J.; Kum, K.Y.; Yun, C.H.; Han, S.H. A 15-amino acid C-terminal peptide of beta-defensin-3 inhibits bone resorption by inhibiting the osteoclast differentiation and disrupting podosome belt formation. J. Mol. Med. 2017, 95, 1315-1325. [CrossRef] [PubMed] 
44. Li, Q.; Kumar, A.; Gui, J.F.; Yu, F.S. Staphylococcus aureus lipoproteins trigger human corneal epithelial innate response through toll-like receptor-2. Microb. Pathog. 2008, 44, 426-434. [CrossRef] [PubMed]

45. Lee, J.Y.; Lee, B.H.; Lee, J.Y. Gambogic Acid Disrupts Toll-like Receptor4 Activation by Blocking Lipopolysaccharides Binding to Myeloid Differentiation Factor 2. Toxicol. Res. 2015, 31, 11-16. [CrossRef] [PubMed]

(C) 2019 by the authors. Licensee MDPI, Basel, Switzerland. This article is an open access article distributed under the terms and conditions of the Creative Commons Attribution (CC BY) license (http://creativecommons.org/licenses/by/4.0/). 